\title{
Adrenoceptors Modulate Cholinergic Synaptic Transmission at the Neuromuscular Junction
}

\author{
Ellya Bukharaeva *, Venera Khuzakhmetova, Svetlana Dmitrieva and Andrei Tsentsevitsky
}

Citation: Bukharaeva, E.;

Khuzakhmetova, V.; Dmitrieva, S.;

Tsentsevitsky, A. Adrenoceptors

Modulate Cholinergic Synaptic Transmission at the Neuromuscular Junction. Int. J. Mol. Sci. 2021, 22, 4611. https://doi.org/10.3390/ ijms22094611

Academic Editor: Julie Perroy

Received: 31 March 2021

Accepted: 26 April 2021

Published: 28 April 2021

Publisher's Note: MDPI stays neutra with regard to jurisdictional claims in published maps and institutional affiliations.

Copyright: (c) 2021 by the authors. Licensee MDPI, Basel, Switzerland. This article is an open access article distributed under the terms and conditions of the Creative Commons Attribution (CC BY) license (https:// creativecommons.org/licenses/by/ $4.0 /)$.
Kazan Institute of Biochemistry and Biophysics, FRC Kazan Scientific Center of RAS, 420111 Kazan, Russia; venerik87@mail.ru (V.K.); s_dmitrieva@list.ru (S.D.); atsen@list.ru (A.T.)

* Correspondence: ellyab@mail.ru

\begin{abstract}
Adrenoceptor activators and blockers are widely used clinically for the treatment of cardiovascular and pulmonary disorders. More recently, adrenergic agents have also been used to treat neurodegenerative diseases. Recent studies indicate a location of sympathetic varicosities in close proximity to neuromuscular junctions. The pressing question is whether there could be any effects of endo- or exogenous catecholamines on cholinergic neuromuscular transmission. It was shown that the pharmacological stimulation of adrenoceptors, as well as sympathectomy, can affect both acetylcholine release from motor nerve terminals and the functioning of postsynaptic acetylcholine receptors. In this review, we discuss the recent data regarding the effects of adrenergic drugs on neurotransmission at the neuromuscular junction. The elucidation of the molecular mechanisms by which the clinically relevant adrenomimetics and adrenoblockers regulate quantal acetylcholine release from the presynaptic nerve terminals and postsynaptic sensitivity may help in the design of highly effective and well-tolerated sympathomimetics for treating a number of neurodegenerative diseases accompanied by synaptic defects.
\end{abstract}

Keywords: synaptic transmission; neuromuscular junction; adrenergic drugs; adrenoreceptors; acetylcholine quantal release; acetylcholine receptor

\section{Introduction}

The neuromuscular junction (NMJ) is the main element in the nerve stimulus transmission and the trigger for muscle contraction. Despite the long history of its study, there are still many questions about the mechanisms of the modulation of its functions in physiological and pathological states [1,2]. Two key processes provide information transfer at the NMJ: at first, a few tens of acetylcholine (ACh) quanta release from the nerve ending into the synaptic cleft after motoneuron stimulation, and secondly, there is an interaction between ACh molecules and postsynaptic ACh receptors which generates postsynaptic responses or end plate potentials (EPPs). If a sufficient number of ACh quanta are released in reply to a nerve stimulus and the EPPs amplitude reaches the critical level of muscle fiber membrane depolarization, then muscle contraction will occur. Numerous complex intracellular processes provide both the secretion of ACh quanta and the generation of muscle contraction after the activation of ACh receptors. Function disruptions of each part of the NMJ cause impaired synaptic transmission and muscle weakness [3].

In the end 19th century, it was discovered that adrenaline and noradrenaline from extracts of the suprarenal capsules increase muscle contractions [4,5]. By investigating the influence of sympathetic nerve stimulation on the skeletal muscle, Orbeli [6] and Ginetsinsky [7] found that the excitability and contractility of muscles that were fatigued due to prolonged motor nerve stimulation increased after nervus vagus excitation, which leads to the release of noradrenaline. This effect was called Orbeli-Ginetsinsky phenomenon. However, for a long time, it was not clear how catecholamines act on the NMJ and improve the skeletal muscle functions. 
In the last decade, the number of publications on the effects of the sympathetic nervous system and sympathomimetics on the contractile functions of skeletal muscles has significantly increased [8-13]. Most of the works describe the action of adrenergic drugs on muscle contractions, but there is much less information regarding changes in synaptic transmission. The primary goal of this review is to discuss modern experimental data regarding the effects of adrenergic receptors activators and blockers on the quantal $\mathrm{ACh}$ secretion and ACh receptor function at the NMJ. This knowledge is very relevant since adrenergic compounds are widely used clinically in cardiovascular and pulmonary diseases, as well as in combination with muscle relaxants and anesthetics in surgical practice. Adrenoceptor agonists began to be offered for a treatment of wide range of neurodegenerative pathologies such as congenital myasthenic syndromes [14-17], antiMuSK myasthenia gravis [18] and amyotrophic lateral sclerosis [19]. In recent years, experimental interest has further expanded the treatment for a wide range of muscle wasting diseases, spinal muscular atrophy and sarcopenia $[13,20,21]$. At the same time, it is very important to understand how adrenergic receptor activators and blockers used clinically act on the main processes of synaptic transmission in normal conditions without any pathologies. This is one of the important tasks of this review.

\section{Activators and Blockers of Adrenergic Receptors Alter the Spontaneous ACh Quantal Release at the NMJ}

Without nerve stimulation, ACh quanta are released from the nerve endings spontaneously, generating miniature endplate potentials (MEPPs). The average MEPP frequency is a parameter characterizing the intensity of the secretory process in the synapse at rest [22]. There are plenty of data which indicate that adrenaline or the addition of noradrenaline to the NMJ increases the MEPP frequency [23-25].

There are different subtypes of the adrenoceptors for the realization of adrenaline and noradrenaline action [26]. Many experiments have been carried out with a specific agonists and antagonists. $\alpha$-adrenoceptor activator phenylephrine increased the MEPP frequency and $\alpha 1$-adrenoceptor blocker prazosin eliminated this effect [27]. It was suggested existence of a presynaptic $\alpha 1$-adrenoceptor in the motor neuron terminal and suggest that modulation of transmitter release might be mediated by inositol triphosphate release, $\mathrm{Ca}^{2+}$ release into the cytosol and activation of a calmodulin-dependent system [27].

$\alpha 2$-adrenoceptor activation by clonidine and xylazine also caused an increase in MEPP frequency at the rat diaphragm NMJ, and it was eliminated by $\alpha$-adrenoceptor blockers phentolamine, prazosin and yohimbine, suggesting the presence of presynaptic $\alpha 1$ - and $\alpha 2$-adrenoceptors [28]. Two sympathomimetic agents used in clinical practice, salbutamol and clenbuterol, activated $\beta 2$-adrenoceptors and induced the elevation of spontaneous ACh secretion in mouse preparations of peroneal nerves and lumbricalis muscles [9,29].

In contrast to these data, we observed opposite effects of the adrenergic drugs on spontaneous ACh quantal release at the mouse diaphragm NMJ at a low calcium $\left(\mathrm{Ca}^{2+}\right)$ concentration [30]. $\alpha 1$ - and $\alpha 2$-adrenoceptor activation by phenylephrine, dexmedetomidine and clonidine decreased the MEPP frequency. Previously, we observed the same effects for adrenaline and noradrenaline. The noradrenaline effect was prevented by the $\beta$-adrenoceptor blocker propranolol, whereas the adrenaline action was prevented by the $\alpha$-adrenoceptor antagonist phentolamine [30,31]. The action of specific $\alpha 1$ - and $\alpha 2$-adrenoceptor agonists was eliminated by blockers of $\alpha 1$-receptors doxazosin and $\alpha 2$ receptors SKF86466. $\beta 1$-receptor activation by xamoterol also decreased the MEPP frequency $[29,30]$. The described evidences suggests the participation of various adrenoceptor subtypes in spontaneous ACh quanta secretion modulation.

The differences in the data concerning the action of the adrenergic drugs on spontaneous $\mathrm{ACh}$ release may be related to various experimental conditions. It was shown that sympathomimetic action on ACh secretion depends on the initial depolarization of the nerve terminal $[23-25,27]$ or on extracellular calcium, sodium and magnesium ion concentration [32]. The increase in spontaneous $\mathrm{ACh}$ release by $\beta 2$-agonists was absent 
in the low $\mathrm{Ca}^{2+}$ concentration and the TRPV1 channel activator arvanil conditions. It was suggested that sympathomimetic effects are induced by $\mathrm{Ca}^{2+}$ input in the nerve terminal which enhances ACh secretion. TRPV1 channel activation mediates $\mathrm{Ca}^{2+}$ conductance in the motor axon terminal and modulates synaptic vesicle release. When TRPV1 channels are activated by arvanil, clenbuterol does not increase the MEPP frequency [29].

The opposite effect, i.e., a decrease in spontaneous ACh secretion under adrenoceptor activation, may be due to the hyperpolarization of the nerve endings. The inhibitory effects of adrenergic drugs were blocked by $\beta$-adrenoceptor antagonists and were caused by axon membrane hyperpolarization [33]. Anderson and Harvey [34] observed an increase in the amplitude of perineural action current components, which could be a result of the hyperpolarization of the motor nerve ending in response to noradrenaline action. Wessler et al. [35] and Starke et al. [36] assumed that adrenaline and noradrenaline have opposing effects on ACh quantal release, initial facilitation and secondary inhibition, on NMJ transmission.

\section{Sympathomimetic Effects on ACh Quantal Release Evoked by the Nerve Stimulus}

In a physiological state, the NMJ operates in a rhythmic stimulation mode, and ACh quantal release evoked by motor nerve pulses induces muscle contraction. The number of synaptic vesicles released after nerve stimulus (the average quantal content) is a quantitative characteristic of the evoked ACh release. This determines the amplitude of the evoked synaptic response, i.e., the endplate potential (EPP) and muscle contraction initiation.

\subsection{Modulation of the Number of ACh Released Quanta}

Various results were obtained in the studies of the effects of adrenergic drugs on the evoked EPP amplitude and EPP quantal content. Kuba [24] and Kuba and Tomito [25] showed that noradrenaline and adrenaline increased EPP amplitude via the activation of presynaptic $\alpha$-adrenoceptors. Wessler et al. [35,37-39] observed that $\alpha$-and $\beta$-adrenoceptor stimulation mediated the increase in labeled ACh release in rat diaphragm synapses. Noradrenaline, adrenaline and phenylephrine facilitated $3 \mathrm{H}$-acetylcholine evoked release. This effect was more marked when the prejunctional nicotinic receptors, mediating positive feedback modulation, were blocked by (+)-tubocurarine. Upon the application of this drug, when the $3 \mathrm{H}$-acetylcholine release was reduced, $\alpha 1$-adrenoceptor agonists enhanced the release in a prazosin-sensitive manner. It is suggested, therefore, that endogenous catecholamines may be able to affect neuromuscular transmission through the stimulation of presynaptic $\alpha 1$-adrenoceptors [40].

Other works have shown that the stimulation of $\beta$-adrenoceptors enhances transmitter output from the motor nerve. It was proposed that these $\beta$-adrenoceptors are of the $\beta 1$ subtype and are localized on the motor nerve endings. Endogenous catecholamines may facilitate neuromuscular transmission by the stimulation of presynaptic $\beta$-adrenoceptors [37].

Snider and Gerald [41], using a radioenzymatic assay, showed an increase in nervestimulated ACh release induced by noradrenaline via presynaptic $\alpha 1$-adrenoceptors. However, noradrenaline did not cause any change in the evoked quantal secretion in the experiments of Lim and Muir [28], whereas clonidine, phenylephrine and xylazine enhanced EPP amplitude, which was blocked by prazosin and yohimbine. In Chiou and Chang's [42] experiments, the EPP quantal content was unaffected by clonidine, although the amplitudes of EPPs and MEPPs were markedly decreased. Our experiments on the rat soleus NMJ showed that noradrenaline did not change the number of released quanta in response to nerve stimulation. However, adrenaline at the same concentration increased evoked ACh quantal release [43]. At the diaphragm NMJ of mice in low extracellular $\mathrm{Ca}^{2+}$, the activation of $\alpha 1$-adrenoceptors by phenylephrine did not change the EPP quantal content. $\alpha 2$-receptor agonists clonidine and dexmedetomidine, as well as the $\beta 1$-agonist xamoterol, reduced the EPP quantal content. Specific antagonists SKF and atenolol prevented the effects of activators. In contrast, procaterol, a $\beta 2$-adrenoceptor agonist, slightly but significantly increased the EPP quantal content [30]. The oppositely directed action of 
the different types of adrenergic receptors activators may cause no effect of noradrenaline on the EPP quantal content $[28,31]$.

Recently, Rodrigues et al. [29] also showed the involvement of presynaptic $\beta 2$-adrenoceptors in the modulation of evoked ACh quantal release. $\beta 2$-agonists salbutamol and clenbuterol increased evoked ACh synaptic vesicle release. This effect was mediated by presynaptic $\omega$-agatoxin IVA-sensitive P/Q-type, $\omega$-conotoxin GVIA-sensitive $\mathrm{N}$-type $\mathrm{Ca}^{2+}$-channels and arvanil-sensitive TRPV1 channels.

Differences in the manifestations of the effects of adrenergic compounds on the amount of released ACh quanta are associated with the activation of the various adrenoceptor subtypes and different intracellular systems involved in the subsequent events leading to ACh release alteration. Adrenoceptor agonists are able to exert dual pharmacological effects, coupling to Gi and Gs proteins to inhibit or stimulate adenylyl cyclase activity [44]. At low agonist concentrations, $\alpha 2$-receptors primarily couple to $\mathrm{Gi}$, whereas at high concentrations, Gs coupling dominate [45]. Starke et al. [36] supported the concept that the activation of terminal receptors coupled to G-proteins inhibits voltage-sensitive $\mathrm{Ca}^{2+}$ channels. L-type $\mathrm{Ca}^{2+}$-channels controlled by presynaptic $\alpha 1$-adrenoceptors at the motor nerve can be opened either directly or indirectly by second messengers (phosphoinositides, diacylglycerol, cyclic nucleotides) [35,36,44]. The mechanisms governing downstream $\alpha 2$ adrenoceptors activation are controversial; $\alpha 2$-adrenoceptor agonists can open potassium channels [44,46], inhibit voltage-dependent $\mathrm{Ca}^{2+}$-channels $[47,48]$ and inhibit adenylyl cyclase [49-51].

Based on the available experimental data, it can be concluded that at the peripheral NMJ, there may be adrenoceptors of both $\alpha$ and $\beta$ types, which modulate ACh secretion from motor nerve endings, increasing or decreasing it. The direction and effectiveness of such modulating effect depends on the experimental conditions (extracellular $\mathrm{Ca}^{2+}$ concentration, magnesium or sodium ions and the methods of muscle fiber contractions blocking), the type of muscle fibers and the functional accessory of muscles.

\subsection{Modulation of the Kinetics of ACh Quantal Release}

It is generally accepted that in addition to quantal content, another important characteristic of evoked neurotransmitter release is the kinetics or time course of ACh quantal secretion [52-54]. The release of several tens of ACh quanta in response to a single nerve stimulus does not occur simultaneously $[52,53,55]$. The asynchrony of individual quanta secretion is manifested by the dispersion of real synaptic delays of uni-quantal EPPs recorded in low $\mathrm{Ca}^{2+} / \mathrm{high} \mathrm{Mg}^{2+}$ conditions $[52,55]$ or by a greater increase in the rise time of multi-quantal EPP compared to the MEPP rise time [56,57]. More synchronous release of quanta leads to the EPP amplitude increasing and thus facilitates synaptic transmission [58] (Figure 1).

We have previously shown that noradrenaline synchronizes evoked ACh quantal release without quantal content change at the frog NMJ [59] (Figure 2).

Pharmacological analysis with specific agonists and antagonists of the adrenoceptors showed that the synchronizing effect of noradrenaline is due to the activation of presynaptic $\beta 1$-adrenergic receptors. The sequence of intracellular events that occur after the activation of presynaptic $\beta 1$-adrenoceptors by noradrenaline includes the activation of adenylyl cyclase, an increase in the intracellular level of cAMP, activation of protein kinase A and phosphorylation of synaptic proteins, leading to an acceleration of exocytosis of the contents of synaptic vesicles [60] (Figure 3).

It was shown that the synchronizing action of noradrenaline leads to an increase in the amplitude of the multiquantal current of the end plate in the "fatigued" muscle and underlies the Orbeli-Ginetsinsky phenomenon-an increase in muscle contractions upon stimulation of the sympathetic nerve [6,7]. Therefore, the synchronization of ACh secretion may be a mechanism for the facilitating action of the sympathomimetics [58]. 


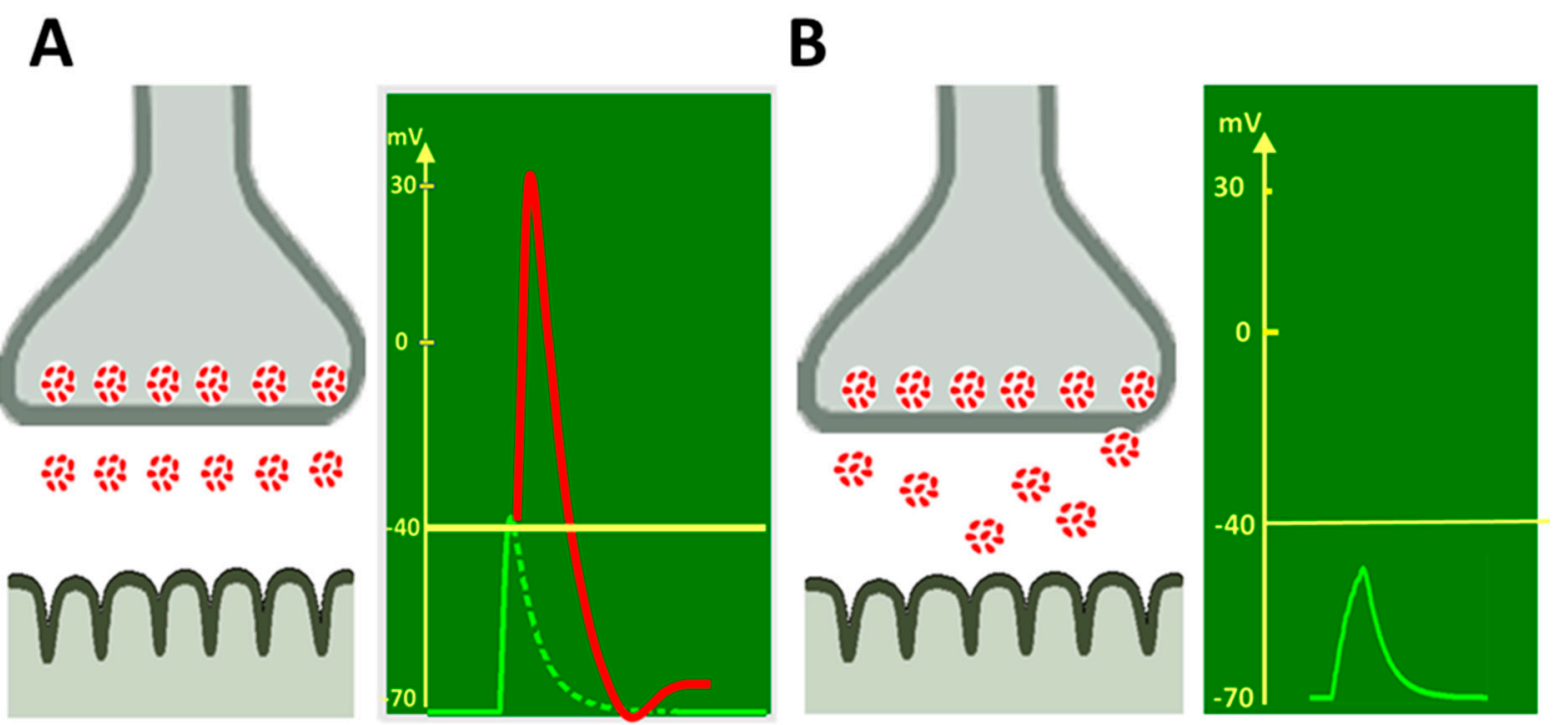

Figure 1. Synchronous and asynchronous ACh quanta release at NMJ. (A) Synchronous release of ACh quanta from nerve terminal triggers EPP in the muscle fiber with sufficient amplitude (green line), needed to generate action potential (red line) and subsequent muscle contraction. (B) Asynchronous release of ACh quanta triggers smaller signal (green line) in the muscle fiber, insufficient to cause action potential generation and muscle fiber contraction.

A

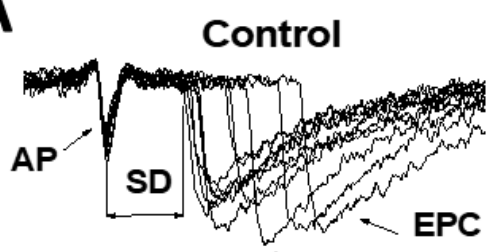

Noradrenaline (Isoproterenol, Dobutamine)
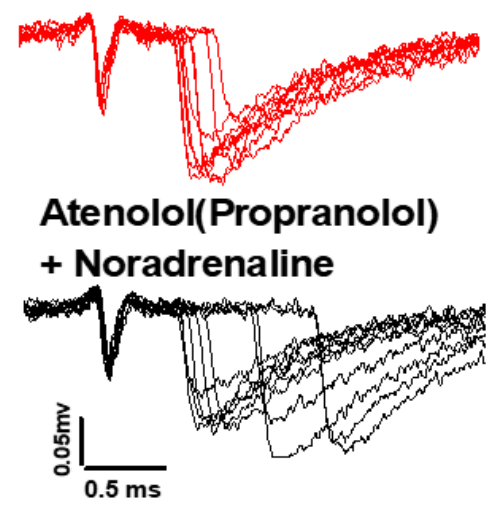

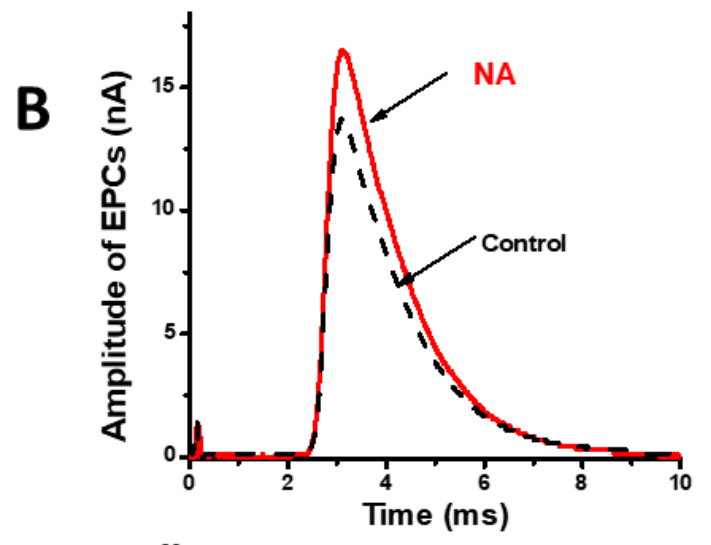

C

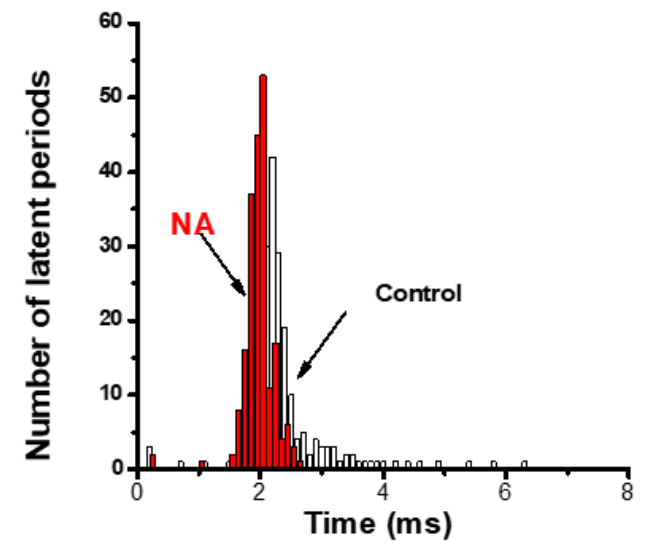

Figure 2. Noradrenaline and $\beta 1$ adrenoceptors agonists effects at frog NMJ. (A) decrease of the synaptic delays (SD) fluctuations of extracellular uni-quantal EPCs (end plate currents) in the presence of noradrenaline or agonists of $\beta 1$ adrenoceptors (middle panel), synaptic delays after noradrenaline addition in presence $\beta 1$ adrenoceptor blockers; (B) intracellular multi-quantal EPC has higher amplitude after noradrenaline application without increase of EPC quantal content; (C) histograms of synaptic delays distributions in control and after noradrenaline application. AP-axon action potential; NA-noradrenaline. 


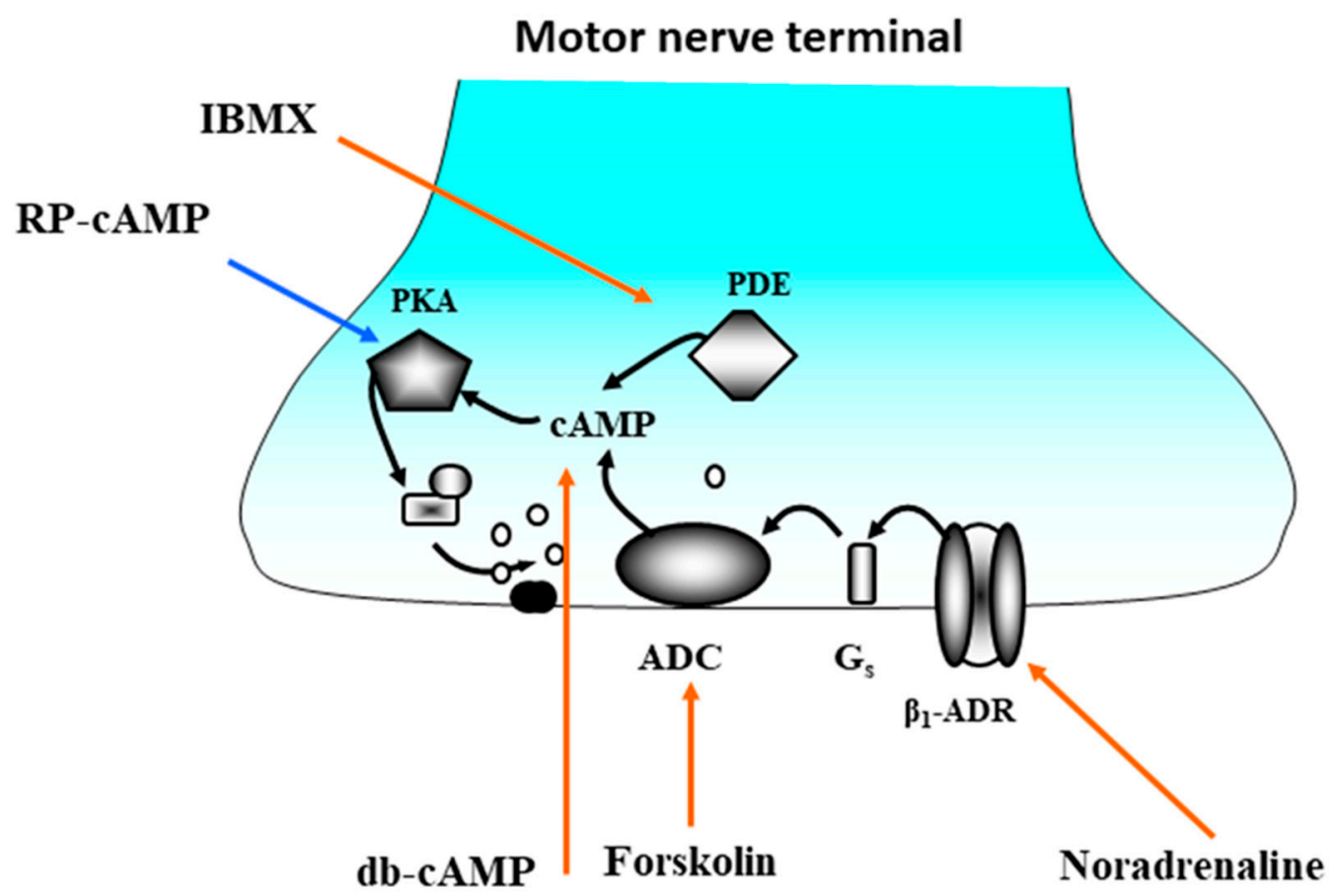

Figure 3. $\beta 1$-adrenoceptor activation by noradrenaline causes the synchronization of ACh quanta release at frog NMJ by participation of Gs protein, activation of adenylyl cyclase (ADC), increase in cAMP production and proteinkinase A (PKA) activation. Red arrows show synchronizing action of noradrenaline, activator of ADC forskoline, db-cAMP-permeable derivative of cAMP, phosphodiesterase (PDE) inhibitor isobutylmethylxanthine (IBMX). Stimulation-evoked EPCs with long release latencies were eliminated when the intracellular cAMP was increased by $\beta 1$-adrenoceptor activation by noradrenaline, by the permeable analogue db-cAMP, by activation of adenylyl cyclase or by inhibition of cAMP hydrolysis. Protein kinase A is a target of this regulation, since a specific inhibitor, Rp-cAMP, prevents the action of cAMP and noradrenaline [60].

Quantal secretion asynchrony is determined by various factors, such as $\mathrm{Ca}^{2+}$ entry into the nerve terminal, intracellular $\mathrm{Ca}^{2+}$ buffer activity, exocytosis proteins and intracellular enzyme systems $[55,61]$. It was shown previously that the degree of secretion synchronization at the mouse NMJ depends on $\mathrm{Ca}^{2+}$ entry into the nerve ending. The synchrony of quantal secretion increased with the growth of extracellular $\mathrm{Ca}^{2+}$ [55]. This relationship is since intracellular $\mathrm{Ca}^{2+}$ determines the rate of $\mathrm{Ca}^{2+}$ activated vesicular fusion, so that higher $\mathrm{Ca}^{2+}$ accelerates the rate of the release reaction and induces short synaptic delays. [55,62]. Recently, we investigated the effects of adrenergic drugs on the kinetics of ACh quantal release at mammal NMJs. In our experiments, adrenaline increased spontaneous and evoked quantal $\mathrm{ACh}$ release at the NMJ of the hindlimb soleus muscle and synchronized evoked ACh quantal secretion [43]. We suggested that the facilitation of the synaptic transmission by adrenaline is due to the increased $\mathrm{Ca}^{2+}$ entering the axoplasm. There is evidence that sympathomimetics affect the activity of voltage gated $\mathrm{Ca}^{2+}$ channels $[29,39,62]$, which may be the mechanism of the effect of adrenoreceptor activation on the kinetics of secretion.

However, at the mouse diaphragm NMJ, the opposite desynchronization effect of noradrenaline was observed, and both $\alpha$ - and $\beta$-receptors were involved in this action [31]. In contrast to the observations at frog and soleus muscle NMJ, data obtained demonstrate that the activation of $\alpha 2$-adrenoceptors by dexmedetomidine and $\beta 2$-adrenoceptors by procaterol increased the ACh quantal secretion asynchrony at mouse diaphragm. These effects were eliminated by $\alpha 2$ - and $\beta 2$-adrenoceptor blockers $[30,31]$.

Thus, the analysis of the effects of adrenergic drugs on the ACh quantal release at the NMJ showed diverse modulation of the spontaneous and evoked ACh quantal release from motor nerve endings in response to the activation of various subtypes of adrenergic 
receptors (Table 1). Obviously, further research is required to understand the features and mechanisms of adrenergic drugs action on the ACh quantal secretion.

Table 1. Effects of agonists of various types of adrenergic receptors on the quantal ACh release.

\begin{tabular}{|c|c|c|c|c|c|c|}
\hline \multirow{3}{*}{ ADR } & \multirow{2}{*}{\multicolumn{2}{|c|}{ Spontaneous ACh Release }} & \multicolumn{4}{|c|}{ Evoked ACh Release } \\
\hline & & & \multicolumn{2}{|c|}{ Quantal Content } & \multicolumn{2}{|c|}{ Secretion Kinetics } \\
\hline & Inhibition & Facilitation & Inhibition & Facilitation & Synchronization & Desynchronization \\
\hline$\alpha$ & $\begin{array}{l}\text { Adrenaline * } \\
\text { Noradrenaline * } \\
\text { Phenylephrine * } \\
\text { Dexmedetomidine * } \\
\text { Clonidine * } \\
{[30,31,49]}\end{array}$ & $\begin{array}{l}\text { Noradrenaline } \\
{[23,24]} \\
\text { Adrenaline [25] }\end{array}$ & & $\begin{array}{l}\text { Noradrenaline } \\
\text { Adrenaline } \\
\alpha \text {-methylnor- } \\
\text { adrenaline } \\
{[32,33]}\end{array}$ & $\begin{array}{l}\text { Adrenaline * } \\
{[30,31]}\end{array}$ & $\begin{array}{l}\text { Noradrenaline * } \\
{[30,31]}\end{array}$ \\
\hline$\beta$ & & $\begin{array}{l}\text { Noradrenaline } \\
\text { [24] }\end{array}$ & & $\begin{array}{l}\text { Isoprenaline } \\
\text { Noradrenaline } \\
{[23,24,32,33,35,37]}\end{array}$ & & \\
\hline$\alpha 1$ & Phenylephrine [31] & $\begin{array}{l}\text { Phenylephrine }{ }^{\mathrm{K}} \\
{[27,41]}\end{array}$ & & $\begin{array}{l}\text { Phenylephrine } \\
{[33,38,40]}\end{array}$ & $\begin{array}{l}\text { Adrenaline * } \\
{[30,31]}\end{array}$ & \\
\hline$\alpha 2$ & $\begin{array}{l}\text { Dexmedetomidine * } \\
\text { Clonidine * } \\
\text { [30] }\end{array}$ & $\begin{array}{l}\text { Clonidine Xylazine } \\
\text { [28] }\end{array}$ & $\begin{array}{l}\text { Clonidine * } \\
\text { Dexmedetomidine * } \\
\text { [30] }\end{array}$ & & $\begin{array}{l}\text { Adrenaline * } \\
{[31,43]}\end{array}$ & $\begin{array}{l}\text { Dexmedetomidine } \\
{[30]^{*}}\end{array}$ \\
\hline$\beta 1$ & $\begin{array}{l}\text { Xamoterol * } \\
{[30]}\end{array}$ & Isoproterenol [25] & $\begin{array}{l}\text { Xamoterol * } \\
{[30]}\end{array}$ & $\begin{array}{l}\text { Isoprenaline } \\
{[27,37,39]}\end{array}$ & $\begin{array}{l}\text { Noradrenaline } \\
\text { [59] }\end{array}$ & \\
\hline$\beta 2$ & & $\begin{array}{l}\text { Salbutamol } \\
\text { Clenbuterol } \\
{[9,29]}\end{array}$ & & $\begin{array}{l}\text { Salbutamol } \\
\text { Clenbuterol } \\
\text { Procaterol * } \\
{[9,29]}\end{array}$ & & $\begin{array}{l}\text { Procaterol * } \\
{[30]}\end{array}$ \\
\hline
\end{tabular}

Adrenoceptor (ADR) agonists affecting the parameters of the quantal ACh release, acting on different subtypes receptor are presented. Noradrenaline and adrenaline can interact with both $\alpha$ and $\beta$ receptors, therefore their effects are related $\alpha$ (or $\beta$ ) receptors if they are eliminated by $\alpha$ (or $\beta$ ) blockers respectively. Different experimental condition: ${ }^{*}$ - Low extracellular $\left[\mathrm{Ca}^{2+}\right]_{0}$ concentration; ${ }^{\mathrm{K}}$-High extracellular potassium concentration; [30]—reference number.

\section{Effects of Adrenergic Drugs on the Postsynaptic Nicotinic Receptors at the NMJ}

Adrenergic drugs act not only on the release of ACh quanta. There are numerous data regarding the state of $\mathrm{ACh}$ receptors changing on the postsynaptic membrane of muscle fibers in response to catecholamine action. As mentioned above, the interaction of $\mathrm{ACh}$ molecules with their postsynaptic receptors determines the amplitude of postsynaptic potential and the onset of muscle contraction. For the estimation of ACh receptor functions, analysis of the amplitude-temporal parameters of miniature end plate current (MEPC) was used. The MEPC amplitude is affected by the number of ACh molecules per quanta and by the single channel conductance. It was shown that albuterol, ephedrine and pseudoephedrine acted as a fast-acting channel blocker of ACh receptors [63,64]. Ephedrine decreased MEPP amplitude. It reduced the channel conductance but had no effect on the channel's open state duration [64]. The ACh receptor channel blocking effect of ephedrine and pseudoephedrine reduced the synaptic transmission that occurs in the slow-channel myasthenic syndromes or endplate acetylcholinesterase deficiency [65]. We did not observe significant changes of the MEPP amplitude-temporal parameters in response to phenylephrine, doxazosin, dexmedetomidine or clonidine application at the mouse diaphragm NMJ. This indicates the absence of postsynaptic $\alpha 1$ - and $\alpha 2$-adrenoceptors at the NMJ. $\beta 1$-receptor agonist xamoterol and its antagonist atenolol also did not change the MEPP parameters. Our data showed the absence of postsynaptic $\beta 1$-adrenoceptor influence on the endplate electrogenesis [30].

In contrast, $\beta 2$-agonist salbutamol induced the significant improvements in several postsynaptic morphological defects including increased synaptic area, density of ACh receptors, extension of postjunctional folds and significant increases in time to peak, halfdecay time and the duration of MEPP at the mouse NMJ with the ColQ myasthenic syndrome model [8]. These effects are mainly manifested at the postsynaptic membrane 
and can lead to enhanced synaptic transmission. Moreover, salbutamol induces a significant increase in the number of $\mathrm{ACh}$ receptor clusters by affecting proteins located at the NMJ $[9,66,67]$. The sympathetic nervous system regulates postsynaptic ACh receptors stability and clustering through the action of endogenous catecholamines on the sarcoplasm proteins G $\alpha$ i2-Hdac4-myogenin-MuRF1 [9].

The data analysis of the postsynaptic action of adrenergic drugs suggests that mainly $\beta 2$-adrenoceptor agonists regulate the nicotinic ionotropic $\mathrm{ACh}$ receptor state at the NMJ. Here, we describe the effects of adrenergic drugs on ACh receptors in the NMJ postsynaptic area. However, there are many data regarding the effects of muscle $\beta 2$-adrenoceptor activation on the intracellular processes in muscle fibers on extrasynaptic zones $[68,69]$. These results require separate consideration.

\section{Morphological Evidence of the Existence of Adrenoceptors at the NMJ}

The data described above suggest the presence of adrenoceptors at the NMJ. Western blotting was used to identify different subtypes of adrenoceptors in the mouse diaphragm. Analysis revealed the presence of $\alpha 1 \mathrm{~A}, \alpha 1 \mathrm{~B}, \alpha 2 \mathrm{~A}, \alpha 2 \mathrm{~B}, \alpha 2 \mathrm{C}$ and $\beta 1$ subtypes of adrenoceptors [30]. Presynaptic $\alpha 2$-adrenoceptors are involved in the downregulation of noradrenaline release from sympathetic axon terminals near the NMJ activating $\mathrm{G} \alpha \mathrm{i} / \mathrm{s}$ protein and inhibiting voltage-gated $\mathrm{N}$-type $\mathrm{Ca}^{2+}$ channels $[8,29,66]$. The postsynaptic effects of $\beta 2$ adrenergic drugs indicate the presence of this type of receptor in the endplate area. Co-localization of $\beta 2$-adrenoceptors with ACh receptors was shown by immunostaining method in mouse gastrocnemius and extensor digitorum longus muscles [8]. This is consistent with the statement that $\beta 2$-adrenoceptors are the dominant subtype in the skeletal muscle of rodents, constituting $80-90 \%$ of the total number of adrenergic receptors [68-70].

Presynaptic action of adrenergic drugs on the ACh release suggests the existence of adrenoceptors at the motor nerve ending. Sympathetic innervation of the NMJs in hindlimb, diaphragm, and levator auris longus muscles is extensive and, in the extensor digitorum longus muscle, increases until adulthood [71]. Immunofluorescence co-expression analysis of immunolabeled adrenoceptors with choline acetyltransferase-, tyrosine hydroxylaseor calcitonin gene-related peptide immunoreactive axons showed that $\alpha 2 \mathrm{~B}$-adrenoceptors were found mainly in sympathetic neurons, and $\beta 1$ type adrenoceptors in sympathetic and motor neurons $[3,29,67,72]$. It was suggested that presynaptic $\beta$-adrenoceptors presumably mediate catecholamine and sympathomimetic effects on motoneuron axonal $\mathrm{Ca}^{2+}$ channels during NMJ activation $[8,9,29]$.

\section{Effects of the Endogenous Catecholamines on Synaptic Transmission}

An intriguing question is whether endogenous adrenaline and noradrenaline are able to affect neuromuscular transmission. Studies using analysis of the localization of NMJ and sympathetic innervation and the elimination of sympathetic influences on the synapse give a positive response.

At the early 20th century, it was found that sympathetic nerve fibers have close contacts with the striated muscles fibers [73]. Later, with the development of immunofluorescence techniques and confocal microscopy, the co-localization of tyrosine hydroxylaze, a marker of sympathetic neurons, and the endplate of the muscle fiber was directly demonstrated $[9,67,71]$.

It was presented evidences that the NMJs of various muscles, such as tibialis anterior, soleus, levator auris longus and diaphragm are directly innervated by sympathetic neurons [11-13]; the innervation starts before birth and actively continues during postnatal development [71].

The influence of adrenoceptor blockers on the synaptic transmission was also observed. $\alpha 2$-adrenoceptor inhibition by SKF 86466 and $\beta 2$-adrenoceptors by ICI 118,551 diminished spontaneously and evoked ACh quantal release. $\beta 1$-adrenoceptor antagonist atenolol synchronized the secretory process [30]. These observations can indicate the action of the endogenous noradrenaline at the NMJ. 
The effects of sympathectomy caused a significant reduction in nerve-evoked muscle contraction [71] and the decrease in ACh quantal release [29], demonstrating the possibility of endogenous catecholamine effects on the synaptic function. It was shown that the sympathetic nervous system controls the organization and function of pre- and postsynaptic cells regulating the expression of genes encoding neurotrophins and motor axon neurofilament phosphorylation. The ablation of the sympathetic innervation leads to the upregulation of several important postsynaptic proteins (LRP4, MuSK, DOK7, MuRF1), muscle atrophy and the downregulation of postsynaptic ACh receptors $[9,29,67]$. Sympathomimetic agents reestablish the muscle action potentials disrupted by chemical ablation of sympathetic innervation [29,71]. Direct stimulation of sympathetic neurons enhances neuromuscular transmission in young mice by catecholamine released from sympathetic axons that act on $\beta$-adrenoceptors expressed in the motoneuron [71]. In contrast, sympathectomy effects on neuromuscular transmission involve disorganization of the cytoskeleton in motor axons, myelination defects, decreases in axon diameter and fiber-type specific reductions in the muscle cross-sectional area $[8,9,29]$.

Thus, it can be concluded that sympathetic innervation provides the presence of endogenous catecholamines near the NMJ and is involved in the modulation of synaptic transmission.

\section{Progress and Perspectives}

Pharmacological analysis of the effects of adrenergic drugs, specific for various adrenoceptors subtypes, showed that the activation and blockade of various subtypes of $\alpha$ - and $\beta$-adrenoceptors modulate ACh quantal release from motor nerve terminals and postsynaptic ACh receptor properties; thus, they can affect the efficiency of synaptic excitation transmission at the NMJ. According to the latest experimental data, $\alpha 1$ - and $\alpha 2$ (subtypes B)-adrenoceptors were found in the presynaptic zones of motor nerve and sympathetic nerve endings. They regulate noradrenaline release from sympathetic varicosities and spontaneous ACh secretion from motor nerve endings. $\beta 1$-adrenoceptors can be localized on sympathetic axons and at the same time on motoneuron endings, whereas $\beta 2$ adrenoceptors are mainly on the muscle fiber membrane. Schwann cells surrounding the neuromuscular synapse may be involved in adrenergic modulation of synaptic transmission. Indeed, adrenaline and noradrenaline application induced the intracellular $\mathrm{Ca}$ concentration increase, raised intracellular cyclic AMP in Schwann cell [74] and, as a consequence, the release of some gliotransmitters adenosine [75] or presumably gammaaminobutyric acid [76,77], which affect the secretion of ACh [78]. These data suggest that $\alpha$ - or $\beta$-adrenoceptors are present on the Schwann cells membrane [79].Endogenous catecholamines and exogenous adrenergic drugs alter the cholinergic synaptic transmission by activating various subtypes of adrenergic receptors, as well as can act on the membrane of motor nerves and on the extrasynaptic membrane of muscle fibers. Based on the available experimental data, it is possible to propose a hypothetical scheme of NMJ with the sympathetic innervation (Figure 4).

We show all the components (pre- and postsynaptic ACh receptors, various subtypes of adrenoceptors, calcium channels) which may participate илисарable to participate in the adrenergic modulation of the NMJ function. The precise molecular mechanisms by which adrenoceptors modulate $\mathrm{ACh}$ quantal release and nicotinic ACh receptor sensitivity is not yet definitively known and requires further study. The main hypotheses suggest that the influence of adrenergic compounds is associated with a change in the $\mathrm{Ca}^{2+}$ input to the motor nerve endings through the potential-sensitive $\mathrm{Ca}^{2+}$ channels and/or with a change in the state of different G-proteins and the activation of the adenylyl cyclase pathway. The effects on postsynaptic ACh receptors are mediated by changes in the state of proteins involved in ACh receptor clustering. 


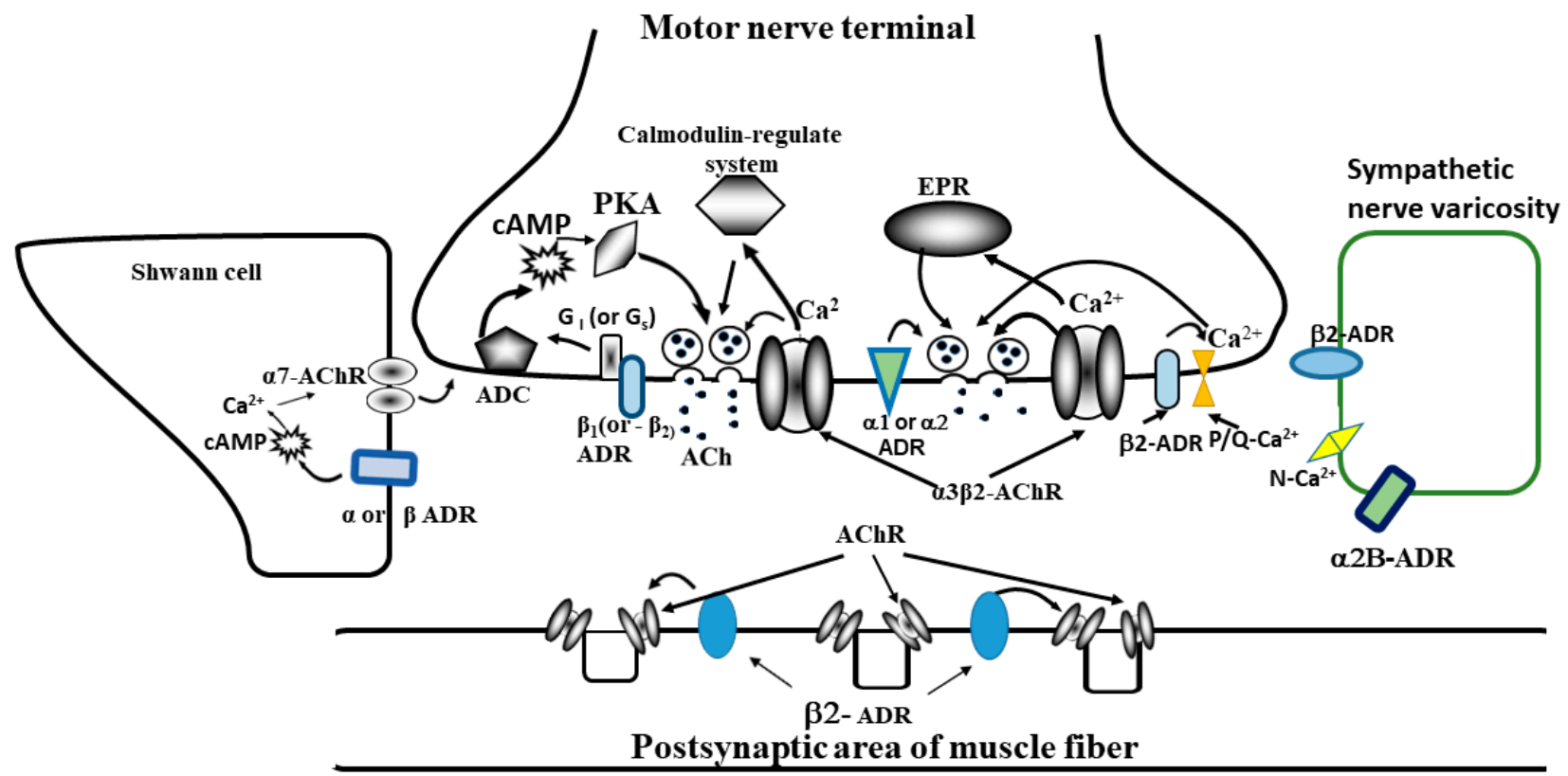

Figure 4. Hypothetical scheme of mammalian NMJ with the sympathetic innervation. ACh-quanta of acetylcholine; ADR—adrenoceptors various types $(\alpha 1, \alpha 2, \alpha 2 B ; \beta 1, \beta 2 ;)$; AChR-postsynaptic ACh receptors; $\alpha 3 \beta 2$-AChR-neuronal presynaptic ACh receptors; $\alpha 7-\mathrm{AChR}$-neuronal AChR receptors in Schwann cell; ADC—adenylate cyclase; cAMP-cyclic adenosine monophosphate; PKA—protein kinase A; EPR—endoplasmic reticulum; Gi or Gs—G-protein; P/Q-Ca ${ }^{2+}$ voltage dependent calcium channel $\mathrm{P} / \mathrm{Q}$ type; $\mathrm{N}-\mathrm{Ca}^{2+}$-voltage dependent calcium channel $\mathrm{N}$ type. Orange arrows show possible action the adrenoceptor's activation.

The interest in research on the interaction of adrenergic and cholinergic receptor systems has grown significantly over the past few years. This is due to the fact that new data are emerging that indicate the important role of sympathetic innervation in providing a better functional state of skeletal muscles during aging and some pathological conditions accompanied by synaptic defects. The therapeutic pre- and postsynaptic benefits of $\beta 2$ adrenoceptor agonists (salbutamol and ephedrine) have been reported in a MuSK myasthenia gravis animal model and in patients with autoimmune myasthenia Gravis and various types of congenital myasthenic syndromes.

Delbone et al. [13] presented a large review of the data obtained from analyzing the interaction of the sympathetic and motor nervous systems and described the importance of modulating the functional state of muscles with endogenous catecholamines and their possible role in the prevention of sarcopenia and muscle weakness with aging. This is very significant for the development of new treatments for muscle weakness in aging and diseases with synaptic defects.

The results reviewed confirm that the sympathetic nervous system has strong and diverse effects on synaptic transmission at the NMJ. All these findings demonstrate a novel mechanism for modulating synaptic transmission based on the interaction between the motor and sympathetic nervous system at the NMJ and stimulate researchers to further study the effects of sympathetic innervation on processes in the somatic peripheral nervous system.

Author Contributions: Conceptualization, E.B.; analysis and writing-original draft preparation, V.K., A.T., S.D.; writing - review and editing, E.B., V.K., A.T. All authors have read and agreed to the published version of the manuscript.

Funding: This research was funded by Russian Science Foundation, grant number 18-15-00046, S.D. was funded by government assignment for FRC Kazan Scientific Center of RAS. 
Institutional Review Board Statement: It was presented previously published data in the Review, which received the relevant necessary opinions of the Ethics Committees, therefore this review was not submitted to the Ethics Committee.

Informed Consent Statement: Not applicable.

Data Availability Statement: Not applicable.

Conflicts of Interest: The authors declare no conflict of interest.

\section{References}

1. Rudolf, R.; Khan, M.; Witzemann, V. Motor endplate-Anatomical, functional, and molecular concepts in the historical perspective. Cells 2019, 8, 387. [CrossRef]

2. Lepore, E.; Casola, I.; Dobrowolny, G.; Musarò, A. Neuromuscular junction as an entity of nerve-muscle communication. Cells 2019, 8, 906. [CrossRef] [PubMed]

3. Cruz, P.R.; Cossins, J.; Beeson, D.; Vincent, A. The Neuromuscular Junction in Health and Disease: Molecular Mechanisms Governing Synaptic Formation and Homeostasis. Front. Mol. Neurosci. 2020, 13, 610964. [CrossRef] [PubMed]

4. Oliver, G.; Schäfer, E.A. The physiological effects of extracts of the suprarenal capsules. J. Physiol. 1895, 18, 230-276. [CrossRef] [PubMed]

5. Vincent, S. On the general physiological effects of extracts of the suprarenal capsules. J. Physiol. 1897, 22, 111-120. [CrossRef] [PubMed]

6. Orbeli, L.A. Die sympatetische Innervation der Skelettmuskeln. Bull. Inst. Sci. Leshaft. 1923, 6, $194-197$.

7. Ginetsinsky, A.G. The influence of the sympathetic nervous system on the function of the striated muscle. Russ. Fiziol. Zhurnal 1923, 6, 139.

8. McMacken, G.M.; Spendiff, S.; Whittaker, R.G.; O'Connor, E.; Howarth, R.M.; Boczonadi, V.; Horvath, R.; Slater, C.R.; Lochmüller, $\mathrm{H}$. Salbutamol modifies the neuromuscular junction in a mouse model of ColQ myasthenic syndrome. Hum. Mol. Genet. 2019, 28, 2339-2351. [CrossRef] [PubMed]

9. $\quad$ Rodrigues, A.C.Z.; Messi, M.L.; Wang, Z.M.; Abba, M.C.; Pereyra, A.; Birbrair, A.; Zhang, T.; O’Meara, M.; Kwan, P.; Lopez, E.I.S.; et al. The sympathetic nervous system regulates skeletal muscle motor innervation and acetylcholine receptor stability. Acta Physiol. 2019, 225, 13195. [CrossRef]

10. Vanhaesebrouck, A.E.; Webster, R.; Maxwell, S.; Rodriguez Cruz, P.; Cossins, J.; Wickens, J.; Liu, W.-W.; Cetin, H.; Cheung, J.; Ramjattan, H.; et al. b2-Adrenergic receptor agonists ameliorate the adverse effect of long-term pyridostigmine on neuromuscular junction structure. BRAIN 2019, 142, 3713-3727. [CrossRef]

11. Wang, Z.M.; Rodrigues, A.C.Z.; Messi, M.L.; Delbono, O. Aging Blunts Sympathetic Neuron Regulation of Motoneurons Synaptic

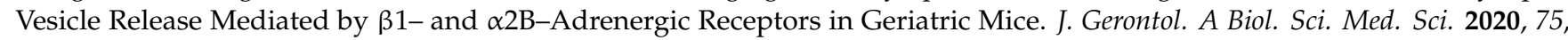
1473-1480. [CrossRef] [PubMed]

12. Wang, Z.M.; Messi, M.L.; Grinevich, V.; Budygin, E.; Delbono, O. Postganglionic sympathetic neurons, but not locus coeruleus optostimulation, activates neuromuscular transmission in the adult mouse in vivo. Cell. Mol. Neurosci. 2020, 109, 103563. [CrossRef] [PubMed]

13. Delbono, O.; Rodrigues, A.C.Z.; Bonilla, H.J.; Messi, M.L. The emerging role of the sympathetic nervous system in skeletal muscle motor innervation and sarcopenia. Age Res. Rev. 2021, 67, 101305. [CrossRef] [PubMed]

14. Engel, A.G.; Shen, X.M.; Selcen, D.; Sine, S.M. Congenital myasthenic syndromes: Pathogenesis, diagnosis, and treatment. Lancet Neurol. 2015, 14, 420-434. [CrossRef]

15. Cruz, P.M.R.; Palace, J.; Beeson, D. The neuromuscular junction and wide heterogeneity of congenital myasthenic syndromes. Int. J. Mol. Sci. 2018, 19, 1677. [CrossRef] [PubMed]

16. Burke, G.; Hiscock, A.; Klein, A.; Niks, E.H.; Main, M.; Manzur, A.Y.; Ng, J.; de Vile, C.; Muntoni, F.; Beeson, D.; et al. Salbutamol benefits children with congenital myasthenic syndrome due to DOK7mutations. Neuromuscul. Disord. 2013, 23, 170-175. [CrossRef]

17. Webster, R.G.; Vanhaesebrouck, A.E.; Maxwell, S.E.; Cossins, J.A.; Liu, W.; Ueta, R.; Yamanashi, Y.; Beeson, D.M.W. Effect of salbutamol on neuromuscular junction function and structure in a mouse model of DOK7 congenital myasthenia. Hum. Mol. Genet. 2020, 29, 2325-2336. [CrossRef]

18. Ghazanfari, N.; Morsch, M.; Tse, N.; Reddel, S.W.; Phillips, W.D. Effects of the B2-adrenoceptor agonist, albuterol, in a mouse model of anti-MuSK myasthenia gravis. PLoS ONE 2014, 9, e87840. [CrossRef]

19. Bartus, R.T.; Bétourné, A.; Basile, A.; Peterson, B.L.; Glass, J.; Boulis, N.M. $\beta 2$-Adrenoceptor agonists as novel, safe and potentially effective therapies for Amyotrophic lateral sclerosis (ALS). Neurobiol. Dis. 2016, 85, 11-24. [CrossRef]

20. Takamori, M. Myasthenia Gravis: From the viewpoint of pathogenicity focusing on acetylcholine receptor clustering, transsynaptic homeostasis and synaptic stability. Front. Mol. Neurosci. 2020, 13, 86. [CrossRef]

21. Limanaqi, F.; Busceti, C.L.; Biagioni, F.; Cantini, F.; Lenzi, P.; Fornai, F. Cell-clearing systems bridging repeat expansion proteotoxicity and neuromuscular junction alterations in ALS and SBMA. Int. J. Mol. Sci. 2020, 21, 4021. [CrossRef] [PubMed]

22. Fatt, P.; Katz, B. Spontaneous subthreshold activity at motor nerve endings. J. Physiol. 1952, 117, 109-128. [PubMed] 
23. Krnjevic, K.; Miledi, R. Some effects produced by adrenaline upon neuromuscular propagation in rats. J. Physiol. 1958, 141, 291-304. [CrossRef] [PubMed]

24. Kuba, K. Effects of catecholamines on the neuromuscular junction in the rat diaphragm. J. Physiol. 1970, 211, 551-570. [CrossRef] [PubMed]

25. Kuba, K.; Tomita, T. Noradrenaline action on nerve terminal in the rat diaphragm. J. Physiol. 1971, $217,19-31$.

26. Bylund, D.B. Alpha- and beta-adrenergic receptors: Ahlquist's landmark hypothesis of a single mediator with two receptors. Am. J. Physiol. Endocrinol. Metab. 2007, 293, E1479-E1481. [CrossRef] [PubMed]

27. Chen, H.; Dryden, W.F.; Singh, Y.N. Transduction of the modulatory effect of catecholamines at the mammalian motor neuron terminal. Synapse 1991, 7, 93-98. [CrossRef]

28. Lim, S.P.; Muir, T.C. Microelectrode recording of the effects of agonists and antagonists on alpha-adrenoceptors on rat somatic nerve terminals. Br. J. Pharmacol. 1983, 80, 41-46.

29. Rodrigues, A.Z.C.; Wang, Z.M.; Messi, M.L.; Delbono, O. Sympathomimetics regulate neuromuscular junction transmission through TRPV1, P/Q- and N-type Ca ${ }^{2+}$ channels. Mol. Cell. Neurosci. 2019, 95, 59-70. [CrossRef]

30. Tsentsevitsky, A.; Nurullin, L.; Tyapkina, O.; Bukharaeva, E. Sympathomimetics regulate quantal acetylcholine release at neuromuscular junctions through various types of adrenoreceptors. Mol. Cell. Neurosci. 2020, 108, 103550. [CrossRef]

31. Tsentsevitsky, A.; Kovyazina, I.; Bukharaeva, E. Diverse effects of noradrenaline and adrenaline on the quantal secretion of acetylcholine at the mouse neuromuscular junction. Neurosci 2019, 423, 162-171. [CrossRef]

32. Bergman, H.; Glusman, S.; Harris-Warrick, R.M.; Kravitz, E.A.; Nussinovitch, I.; Rahamimoff, R. Noradrenaline augments tetanic potentiation of transmitter release by a calcium dependent process. Brain Res. 1981, 214, 200-204. [CrossRef]

33. Bowman, W.C.; Raper, C. Effects of sympathomimetic amines on neuromuscular transmission. Br. J. Pharmacol. Chemother. 1966, 27, 313-331. [CrossRef] [PubMed]

34. Anderson, A.J.; Harvey, A.L. Effects of the facilitatory compounds catechol, guanidine, noradrenaline and phencyclidine on presynaptic currents of mouse motor nerve terminals. Naunyn. Schmiedebergs. Arch. Pharmacol. 1988, 338, 133-1377. [CrossRef] [PubMed]

35. Wessler, I. Acetylcholine at motor nerves: Storage, release, and presynaptic modulation by autoreceptors and adrenoceptors. Int Rev. Neurobiol. 1992, 4, 283-384.

36. Starke, K.; Göthert, M.; Kilbinger, H. Modulation of neurotransmitter release by presynaptic autoreceptors. Physiol. Rev. 1989, 69, 864-989. [CrossRef] [PubMed]

37. Wessler, I.; Anschütz, S. $\beta$-Adrenoceptor stimulation enhances transmitter output from the rat phrenic nerve. Br. J. Pharmacol. 1988, 94, 669-674. [CrossRef] [PubMed]

38. Wessler, I.; Ladwein, E.; Szrama, E. Stimulation of alpha 1-adrenoceptors increases electrically evoked [3H]-acetylcholine release from the rat phrenic nerve. Eur. J. Pharmacol. 1989, 174, 77-83. [CrossRef]

39. Wessler, I.; Holzer, G.; Künster, A. Stimulation of beta 1-adrenoceptors enhances electrically evoked [3H]-acetylcholine release from rat phrenic nerve. Clin. Exp. Pharmacol. Physiol. 1990, 17, 23-32. [CrossRef]

40. Vizi, E.S. Evidence that catecholamines increase acetylcholine release from neuromuscular junction through stimulation of alpha-1 adrenoceptors. Naunyn. Schmiedebergs Arch. Pharmacol. 1991, 343, 435-438. [CrossRef]

41. Snider, R.M.; Gerald, M.C. Noradrenergic-mediated potentiation of acetylcholine release from the phrenic nerve: Evidence for presynaptic alpha 1-adrenoceptor involvement. Life Sci. 1982, 31, 853-857. [CrossRef]

42. Chiou, L.C.; Chang, C.C. Effect of clonidine on neuromuscular transmission and the nicotinic acetylcholine receptor. Proc. Natl. Sci. Counc. Repub. China. B 1984, 8, 148-154.

43. Khuzakhmetova, V.; Bukharaeva, E. Adrenaline Facilitates Synaptic Transmission by Synchronizing Release of Acetylcholine Quanta from Motor Nerve Endings. Cell. Mol. Neurobiol. 2020, 41, 395-401. [CrossRef] [PubMed]

44. Eason, M.G.; Kurose, H.; Holt, B.D.; Raymond, J.R.; Liggett, S.B. Simultaneous coupling of alpha 2-adrenergic receptors to two G-proteins with opposing effects. Subtype-selective coupling of alpha 2C10, alpha 2C4, and alpha 2C2 adrenergic receptors to Gi and Gs. J. Biol. Chem. 1992, 267, 15795-15801. [CrossRef]

45. Sun, H.; Jiang, X.W.; Chang, A.M. Effects of Gi and beta2AR overexpression on the survival of rat cardiac myocytes injured by isoprenaline. Zhongguo Ying Yong Sheng Li Xue Za Zhi 2007, 23, 274-275.

46. Kobilka, B. Adrenergic receptors as models for G protein-coupled receptors. Annu. Rev. Neurosci. 1992, 15, 87-114. [CrossRef] [PubMed]

47. Nakamura, S.; Tepper, J.M.; Young, S.J.; Groves, P.M. Neurophysiological consequences of presynaptic receptor activation: Changes in noradrenergic terminal excitability. Brain Res. 1981, 226, 155-170. [CrossRef]

48. Williams, J.T.; North, R.A. Catecholamine inhibition of calcium action potentials in rat locus coeruleus neurones. Neuroscience 1985, 14, 103-109. [CrossRef]

49. Horn, J.P.; McAfee, D.A. Alpha-drenergic inhibition of calcium-dependent potentials in rat sympathetic neurones. J. Physiol. 1980, 301, 191-204. [CrossRef]

50. Canfield, D.R.; Dunlap, K. Pharmacological characterization of amine receptors on embryonic chick sensory neurones. Br. J. Pharmacol. 1984, 82, 557-565. [CrossRef] 
51. Schoffelmeer, A.N.; Wierenga, E.A.; Mulder, A.H. Role of adenylate cyclase in presynaptic alpha 2-adrenoceptor- and muopioid receptor-mediated inhibition of $[3 \mathrm{H}]$ noradrenaline release from rat brain cortex slices. J. Neurochem. 1986, 46, $1711-1717$. [CrossRef] [PubMed]

52. Katz, B.; Miledi, R. The measurement of synaptic delay, and the time course of acetylcholine release at the neuromuscular junction. Proc. R. Soc. Lond. B Biol. Sci. 1965, 161, 483-495. [PubMed]

53. Barrett, E.F.; Stevens, C.F. The kinetics of transmitter release at the frog neuromuscular junction. J. Physiol. 1972, 227, 691-708. [CrossRef]

54. Kaeser, P.S.; Regehr, W.G. Molecular mechanisms for synchronous, asynchronous, and spontaneous neurotransmitter release. Annu. Rev. Physiol. 2014, 76, 333-363. [CrossRef] [PubMed]

55. Bukharaeva, E.A.; Samigullin, D.; Nikolsky, E.E.; Magazanik, L.G. Modulation of the kinetics of evoked quantal release at mouse neuromuscular junctions by calcium and strontium. J. Neurochem. 2007, 100, 939-949. [CrossRef]

56. Van der Kloot, W. The kinetics of quantal releases during end-plate currents at the frog neuromuscular junction. J. Physiol. 1988, 402, 605-626. [CrossRef] [PubMed]

57. Giniatullin, R.A.; Kheeroug, L.S.; Vyskocil, F. Modelling endplate currents: Dependence on quantum secretion probability and decay of miniature current. Eur. Biophys. J. 1995, 23, 443-446. [CrossRef]

58. Bukharaeva, E.A.; Kim, K.K.; Nikol'skii, E.E.; Vyskochil, F. Synchronization of evoked secretion of quanta of mediator as a mechanism facilitating the action of sympathomimetics. Neurosci. Behav. Physiol. 2000, 30, 139-146. [CrossRef]

59. Bukcharaeva, E.A.; Kim, K.C.; Moravec, J.; Nikolsky, E.E.; Vyskocil, F. Noradrenaline synchronizes evoked quantal release at frog neuromuscular junctions. J. Physiol. 1999, 517, 1469-7793. [CrossRef]

60. Bukharaeva, E.A.; Samigullin, D.; Nikolsky, E.; Vyskocil, F. Protein kinase A cascade regulates quantal release dispersion at frog muscle endplate. J. Physiol. 2002, 538, 837-848. [CrossRef] [PubMed]

61. Schneggenburger, R.; Neher, E. Presynaptic calcium and control of vesicle fusion. Curr. Opin. Neurobiol. 2005, 15, 266-274. [CrossRef] [PubMed]

62. Hara, M.; Zhou, Z.Y.; Hemmings, H.C., Jr. $\alpha 2$-Adrenergic Receptor and Isoflurane Modulation of Presynaptic Ca2+ Influx and Exocytosis in Hippocampal Neurons. Anesthesiology 2016, 125, 535-546. [CrossRef] [PubMed]

63. Milone, M.; Engel, A.G. Block of the endplate acetylcholine receptor channel by the sympathomimetic agents ephedrine, pseudoephedrine, and albuterol. Brain Res. 1996, 740, 346-352. [CrossRef]

64. Sieb, J.P.; Engel, A.G. Ephedrine: Effects on neuromuscular transmission. Brain Res. 1993, 623, 167-171. [CrossRef]

65. Webster, R.G.; Cossins, J.; Lashley, D.; Maxwell, S.; Liu, W.W.; Wickens, J.R.; Martinez-Martinez, P.; de Baets, M.; Beeson, D. A mouse model of the slow channel myasthenic syndrome: Neuromuscular physiology and effects of ephedrine treatment. Exp. Neurol. 2013, 248, 286-298. [CrossRef]

66. Clausen, L.; Cossins, J.; Beeson, D. Beta-2 adrenergic receptor agonists enhance AChR clustering in C2C12 myotubes: Implications for therapy of myasthenic disorders. J. Neuromuscul. Dis. 2018, 5, 231-240. [CrossRef]

67. Khan, M.M.; Lustrino, D.; Silveira, W.A.; Wild, F.; Straka, T.; Issop, Y.; O'Connor, E.; Cox, D.; Reischl, M.; Marquardt, T.; et al. Sympathetic innervation controls homeostasis of neuromuscular junctions in health and disease. Proc. Natl. Acad. Sci. USA 2016, 113, 746-750. [CrossRef] [PubMed]

68. Kim, Y.S.; Sainz, R.; Molenaar, P. Characterization of $\beta 1$ - and $\beta 2$-adrenoreceptors in rat skeletal muscles. Biochem. Pharmacol. 1991, 42, 1783-1789. [CrossRef]

69. Lynch, G.S.; Ryall, J.G. Role of beta-adrenoceptor signaling in skeletal muscle: Implications for muscle wasting and disease. Physiol. Rev. 2008, 88, 729-767. [CrossRef]

70. Silveira, W.A.; Goncalves, D.A.; Graca, F.A.; Andrade-Lopes, A.L.; Bergantin, L.B.; Zanon, N.M.; Godinho, R.O.; Kettelhut, I.C.; Navegantes, L.C. Activating cAMP/PKA signaling in skeletal muscle suppresses the ubiquitin-proteasome-dependent proteolysis: Implications for sympathetic regulation. J. Appl. Physiol. 2014, 117, 11-19. [CrossRef]

71. Straka, T.; Vita, V.; Prokshi, K.; Hörner, S.J.; Khan, M.M.; Pirazzini, M.; Williams, M.P.I.; Hafner, M.; Zaglia, T.; Rudolf, R. Postnatal development and distribution of sympathetic innervation in mouse skeletal muscle. Int. J. Mol. Sci. 2018, 19, 1935. [CrossRef] [PubMed]

72. Khan, M.M.; Strack, S.; Wild, F.; Hanashima, A.; Gasch, A.; Brohm, K.; Reischl, M.; Carnio, S.; Labeit, D.; Sandri, M.; et al. Role of autophagy, SQSTM1, SH3GLB1, and TRIM63 in the turnover of nicotinic acetylcholine receptors. Autophagy 2014, 10, 123-136. [CrossRef] [PubMed]

73. Boeke, J. Die doppelte (motorische und sympathische) erente Innervation der quergestreiften Muskelfasern. Anat. Anz. 1913, 44, 343-356.

74. Yasuda, T.; Sobue, G.; Mitsuma, T.; Takahashi, A. Peptidergic and adrenergic regulation of the intracellular $3^{\prime}, 5^{\prime}$-cyclic adenosine monophosphate content in cultured rat Schwann cells. J. Neurol. Sci. 1988, 88, 315-325. [CrossRef]

75. Noronha-Matos, J.B.; Oliveira, L.; Peixoto, A.; Almeida, L.; Castellão-Santana, M.L.; Ambie, I.; Alves-do Prado, W.; Correia-de-Sá, P. Nicotinic $\alpha 7$ receptor-induced adenosine release from perisynaptic Schwann cells controls acetylcholine spillover from motor endplates. J. Neurochem. 2020, 154, 263-283. [CrossRef]

76. Magnaghi, V.; Parducz, A.; Frasca, A.; Ballabio, M.; Procacci, P.; Racagni, G.; Bonanno, G.; Fumagalli, F. GABA synthesis in Schwann cells is induced by the neuroactive steroid allopregnanolone. J. Neurochem. 2010, 112, 980-990. [CrossRef]

77. Yoon, B.E.; Lee, C.J. GABA as a rising gliotransmitter. Front. Neural Circuits 2014, 8, 141. [CrossRef] 
78. Petrov, K.A.; Girard, E.; Nikitashina, A.D.; Colasante, C.; Bernard, V.; Nurullin, L.; Leroy, J.; Samigullin, D.; Colak, O.; Nikolsky, E.; et al. Schwann cells sense and control acetylcholine spillover at the neuromuscular junction by $\alpha 7$ nicotinic receptors and butyrylcholinesterase. J. Neurosci. 2014, 34, 11870-11883. [CrossRef]

79. Fink, T.; Davey, D.F.; Ansselin, A.D. Glutaminergic and adrenergic receptors expressed on adult guinea pig Schwann cells in vitro. Can. J. Physiol. Pharmacol. 1999, 77, 204-210. [CrossRef] [PubMed] 